\title{
Technical and Vocational Education Now and Beyond in Africa: An implication for Relevance, Growth and Development in the Era of Globalization By Orenaiya, S.A. (Main and Correspondence Author).
}

\author{
Orenaiya Solomon Adewale ${ }^{1}$ Professor. Dr. Hussein Ismail Abdul Gany ${ }^{2}$ \\ Dr. Harison Mohd Sidek ${ }^{3}$ \\ ${ }^{1,3}$ Faculty Of Major Languages Studies Universiti Sains Islam, Malaysia. \\ ${ }^{2}$ Faculty Of Major Languages Studies, Universiti Sains Studies, Malaysia.
}

\begin{abstract}
The problem emanating this study stems from unabated production of university graduates without employment, valueless education and economic recession/political upheavals ravaging Africans, much more the mass employment of expatriates into lucrative source of income and job in construction and production who are products of technical and vocational schools from developed countries. In an longitudinal study of craftsmen, survey and semi-structure interview instruments of collected data to answer research questions such as relevance of technical and vocational education to employability of African graduates, justification of technical and vocational education to improve public image and value, career development and increase income per capital among others. The findings from descriptive statistics showed marked differences in values to the society, patronage and higher contribution to economy. Recommendations includes enlargement, improvement of self-employed craftsmen tostandard, loan equipment, scholarships and incentives to students offering technical and vocational education subjects and courses. This paper concluded that technical and vocational education will provide lifelong trade with general academic studies but with much emphasis on doing/production.
\end{abstract}

Keyword: vocational, technical, education, employment and economy.

\section{Introduction}

Technical and vocational education is an education specifically mapped out to develop occupational and entrepreneurship skills. The goal of education as a concept is to produce an individual who will be useful to self and to the society while technical and vocational education is the concept of educating or illuminating technical and vocational subjects'skills, knowledge and practices beginning from the secondary to the tertiary institutions. The objectives of this paper is to establish relationship of technical and vocational education to entrepreneurship skills, as a developmental progress of technical and vocational education to culture, to also produce graduates of secondary school and technical colleges, to provide learners with intellectual and occupational skills to become entrepreneurs(relevancy). The foundation and progress of growth in technical and vocational skills exhibited by the Asians in the construction, architect and food biotechnology in their region and other parts of the world is concrete evidence that Asian of which Malaysia economy and trade balance of payments as the leading producer of oil palm in the world is a beginning of another block of power in science andtechnology. This had been successfully displayed in the automobile industry which is one of the dividends of investment in technical and vocational education. The underlying strength behind the feat recorded in vocational and technical skills is envisaged in the huge number of trainees in the food centers, hotels and higher institutions where there is large patronage in vocational areas such as variety of foods produced with sophiscated machine under best condition and practicesirrespective of scale of production. The world wide acceptance of entrepreneurship education which comprises of technical,vocational,designing,engineering,repairs of computers had the backing and support of the various Government Policies combined with unwavering interest in these areas was made manifested because of secondary schools and youths already educated and cultured in the skills acquisition thus with the massive investment in education in Malaysia right now is a concretization of skills i.e. formalization of vocational skills and technical related jobs in their society thus One Malaysia Slogan is a modernization and formalization of skills already had in conformity with the postulations of Fayolle,2008.The maintenainance and sustenance of feat achieved in technical and vocational education especially in the varied numbers of engineering schools, polytechnics and technical colleges outnumbered conventional institutions which produce theoretically grounded individuals should tailored in relation to 
goals,content,practice,values,relevancy and contributions. It is quite obvious that they Malaysia is at the right path of achieving her national and international growth and development in the year 2020 .

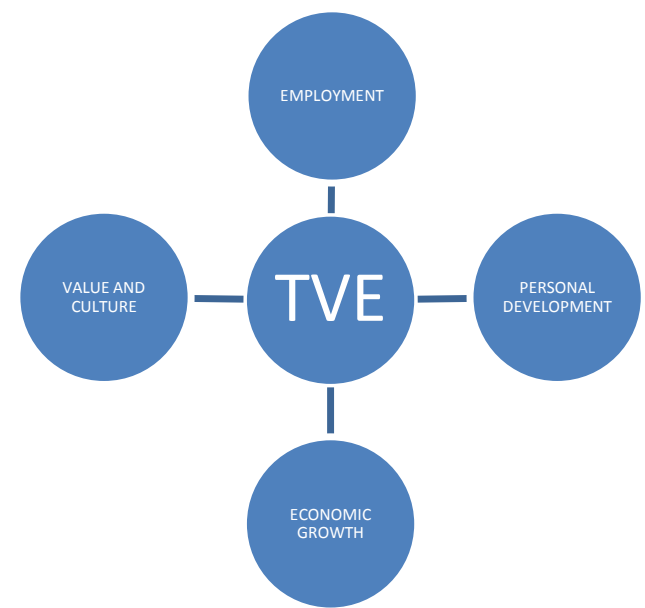

Figure 1: The conceptual representation of Technical Vocational Education (TVE).

\title{
II. Relationships And Differences Between Technical And Vocational Education (Tve)
}

The relationship between the two concepts above is that they are both professionals, experts and creators because they both teaches skills, attitudes,knowledge and rationale of related sciences and technologies, employment careers in promoting social and economic life.

Vocational education is a formal education which prepares the holders to become experts in specific areas of choice technical related jobs in agriculture, foodprocessing, home economics, textiles, cookingetc. Whereas Technical education is a formal education which goes deeper in how to become experts and keeps the task moving through repairing and designing in jobs such as carpentry,construction.welding,engineering and building to mention a few.Therefore, in nature, context and value between the two lies a thin line of separation/demarcation(UNESCO 2013).

\section{Background To The Study}

Many people in the society nursed and perpetuate the notion that failures are associated with technical and vocational skills most especially in Africa because of the long wallowing in mental education in content, nature and scope of education handed over by the colonial masters, the irony is that the colonial lords had since move to industrialized education and scientific education in line with globalization. Another related notion was that university education was the only source of wealth and prestige. The recent waves of technical and vocational educational is increase in establishment and scholarships to technically, scientific and vocationally related schools, this in support of figures quoted by Kuratiko(2005) that 2,200 courses related to technical and vocational/entrepreneurships were in operation in 1,600 institutions all over the world and more than 100 were established and adequately funded by the United States of America pointed them as largest employer of skilled labour in world whose major recruits were from Africans. The growing rate of poverty among the Africans was growing astronomically high than the rate of political and economic basis, this is found in many arrays of antisocial ills committed daily, in fact it has become a menace associated with these populace races in the world. This led to pre-mature withdrawal from secondary schools because of economic demands and possibly less academically oriented, this is similar to Malaysian experience (Malaysian Education Statistics 2011). Those who managed to pass out of secondary school education become youth or young workers to make todays end meet thus these groups of people are in dire needs of technical and vocational educationso as to look beyond today and plan for better tomorrow and enhancement, this is in agreement with the findings of (UNESCO 2004).

\author{
Importance Of Technical \& Vocational Education \\ 1. For skill acquisition. \\ 2. Provision of knowledge and vocational skills. \\ 3. Production of self-reliant individual. \\ 4. Provision of trained manpower in applied science, technology, craft and technical related tasks. \\ 5. Provisionof jobs or employment opportunities.
}




\section{Statement Of The Problem}

The aspirations of parents and prospective students concerning education acquisition is centered on university education, this had discouraged entrant admission into polytechnics, colleges, schools of technologies, schools of vocational and technical skillswhich created undue pressure to engage in examination malpractices, falsification of scores by examination officials and much more the consequences in over production of universities' graduates without jobs (unemployment). The unemployment situation is already skyrocketed and aggravated the youths to engage in anti-vices related behaviours which is a occurrence in Africans and among Africans opportune to reside in developed countries. There was lack of middle income earners and linkage or connection between theory, practice and policy. The unanswered questions remained that can everybody be lawyers, engineers, doctors,managers? If the answer is no, who and where are the supervisors, foremen and workers? Most people had forgotten that if the foremen and their cohorts do not exist, what will university graduates manage,analyse and market?, the way out is to develop technical and vocational education as well as improve local craftsmen and their industry. The problem escalated to the extinction of polytechnic graduates who instead of developing in engineering and creating in practical are now jettisoning practical field for theoretical education in university's theory related courses which are not economically, productive, viable and sustainable, which most often resulted in disengagement from work as a result of economic recession normally bites harder in consuming nations (Africa) than producing and engineering nations (Malaysia, Chinaetc.).Therefore, revolutionizing technical and vocational education will help citizen and nation to achieve the followings;(1)to equip the learners to develop skills for making rationale economic decisions,(ii)to enable individual to relate expertise to the needs of their communities,(iii)to prepare business and industrial managers who will be capable of meeting technological and managerial complexities of modern industry,(iv) to provide the vocational and technical knowledge in various areas of business and (v)to develop citizens properly equipped with the prerequisite knowledge and skills for productive work-life (Federal Ministry of Education,2004\&Ekpenyong,2008.

\section{Nature And Components Of Technical And Vocational Education}

1. The must be a blue-print or road map which entrenches rights and skills to children to own and start a business (Malaysia's children rights and business principles 2013-2015).

2.To promote and support public private partnership in providing technological and vocational education as alternative of creating opportunities for less academically inclined individuals which envisage that no individual is useless to the society.

3. To selectively and purposely guide and tailor the engagement of youths or young workers into responsible employment, this is manifested with university students who owns and runs technical and vocational services to large customers who are mainly students or colleagues.

4. The objectives of the nature of education should be generally oriented one side, with technological and vocational education on the other side.

Objectives Of Technical And Vocational Education(Adapted From Nigeria Npe, 2004)

1. Toprepare responsible citizens who will create jobs rather than being unemployed.

2. To provide lifelong learning.

3. A tool or instrument of preparing for occupation fields/employment generation.

4. Foundation and basics for sustainable development, that is to say that a provider of goods and services is a source of sustenance than consumers/purchasers of goods and services.

5. As alternative form of education apart from conventional or literacy education (Malaysia blue print 20132015).

\section{The Scope Of The Paper}

The target of technical and vocational education to be captured at early stage through the medium of education to which this conference paper focuses are the senior secondary school education and technical colleges in a system of "catch them young" and "incorporating local craftsmen" into the stream of production, improvement and sustainment because they constitute the bedrock and essentially fundamental to technological growth/advancement of citizens and national economy. It must be emphasized that once the values of technical and vocational education are imbibed at this early stage of adolescence and youthful age, it blossoms into National value and culture to be a producer and employer of people rather than waiting to be employed and stimulate their creativity which is the anchor of technological innovations we are enjoying today. The scope of this study/ paper will try to provide answers to the following research questions on how technical and vocational education can contribute to growth, development and sustainability of Malaysia which have implications for Africa economy and growth. 


\section{Conceptual Questions/Research Questions}

1. What is the relevance of technical and vocational education to employability of African Graduates?

2. Of what role would technical and vocational education play in personal development of its beneficiaries?

3. Will technical and vocational education increase public acceptance, recognition and value on its practitioners and beneficiaries?

4. Is there any relationship between technical and vocational education, career development and economic growth?

\section{Objectives Of The Paper}

1. Toencourage and develop value of skills acquisition in creation/production as path of contribution and recognition to the society and country.

2. To re-orientate our brain and mind towards technicalising and vocationalising the Africa continent of which Malaysia and the Asia continent had started, and growing in it.

3. That creation/production skill can generate functional knowledge and value.

4. To remove negative labels associated with technical and vocational education, practioner, beneficiaries and products.

\section{A Review Ofliterature On Technical And Vocational Studies(Tve).}

That all things are equal in term of peace, security and the globalization creating waves across the world in science and technology which is enjoyable by all in banking,education,industry,information and technology, the next line of action demanding and attracting world collaboration is technical and vocational education. Let me review the historical growth and development of technical and vocational education when Columbia Encyclopedia, (2001) reported that manual training involving general instruction in the use of hand tools was said to have developed in scandinava.Vocational education became popular in elementary schools in United States of America and developed into courses in industrial training such as Copper Union in 1859, and various training institutes in $1868,1887,1888$ as well as what the writer can refer to as the foundation when public vocational secondary school was established in 1888 which is an appendage of University of Minnesota. Friedman (1982) commented that technical and vocational education seems deficient in leadership skills and training, yet it could still provide students with the skills needed to become creators, entrepreneurs, and innovators that would enlarge the nation's economic growth and increase personal freedom. The strength of technical and vocational education is what the writer of this paper is emphasizing as a tool for transformation and sustenance of Africa in terms of human and non-human resources, a veritable platform of Malaysia Educational Transformation is built upon which can be applied to Africa situation in some aspect of our educational policy. The various Manpower Development TrainingAct of 1962-1984 on technical and vocational education embarked upon and instituted and judiciously implemented by United States of America was majorly responsible for world power in science and technology accorded America. The Dutch school system also developed an Educational Act to improve provision of vocational education at the secondary school level (Van Ark 1992).

The issue of technical and vocational education had been attracting lots of national and international recognition in Asia. Therefore there is no better time than the race to the next century industrialization of nation, continent of which Africa is at the low level of the ladder of economic growth and transformation. It is on record that lots of international, regional and national conferences are abound in Europe,Asia,America and relatively in Africa(Europeans Commission,2003,2006 \&2008,2010,2012) to deliberate on technical and vocational education /entrepreneurship education. The UNESCO Asian Pacific Innovation in entrepreneurship education also conferenced to clarify issues,limitations,solutions,policies,blue-prints and practices which could be applied in different educational settings of nations(Kafka\&Stephenson,2006).The principles of entrepreneurship education would not be too distant from technical and vocational education which is increasingly gaining wider attention inDenmark, Singapore, potugal,Holland ,Malaysia,India,China and America etc. purposely to create ways of producing new and improved firms and getting rewards(Domuguihos,P. et al 2009).Nigeria in 2002 also had a view on technical and vocational education to begin from the higher education point of view of which the outcome reads thus" Higher education in Nigeria is to provide access to quality post-secondary education which will lead to the production of graduates that are technologically capable and socially well rounded to create jobs and fit well into existing job positions"(Ekpeyong.L.E.2010).Although the writer of this paper is of the opinion that addressing issue of technical and vocational education at the higher level of education is a drain of resources because there is no culture and value of creation and use of hands to produce and the fact that they are trained from the beginning of education to use hands to create(dependent on jobs from Government) as a means of livelihood and value. To be realistic and operate a functional technical and vocational education(TVE) should begin from the secondary school/high school properly while the old days of handwork and crafts should be re- 
incorporated to the primary schools to create and develop interest, values and culture of TVE which will then be built up at the secondary school levels(orenaiya,S.A.2013).

\section{Methodology}

In an observation, longitudinal study and semi-structured interview in a study of two groups of artisans/craftsmen spanning ten years period(2000-20100) between those groups employed by company(A) and other groups who are self-employed(B) in a furniture industry of a private firm named Bisrod System Office Furniture Limited Company in Ijari, via Ijebu-Ode in Ogun State,Nigeria.This study is a survey research combining descriptive and qualitative employed the use of the above instruments to collect information as my participants. The interview was made up of closed and open ended whose questions are the same to avoid digression and facilitate data analysis (Patton 1990, Ary\& Jacob 2006). The participants are graduates ofGovernmentTechnical College in Ijebu-Ode, Ogun State, Nigeria. Using multiple sources of collecting information for research increasescredibility, generalization and compensates for weaknesses of using single source and further the in-depth analysis of investigation (Creswell 2003\&Onwuegbuzie 2004).The constructs on which the study measures are values, relevance, personal development and economic growth while the number of participants used as a study cohort are ten craftsmen in each group to make a population study of twenty participants, also the sampling procedure is convenient sample. Therefore, a simple percentage was used for analysis and reporting because of the small sample which is not stratified across Ogun State or Nigeria.

\section{Findings, Analysis And Discussions}

The group A who are employed in the company that manufactured furniture showed marked differences in experiences on the job, innovation, patronages, values, personaldevelopment, career development and higher contribution to National Gross Domestic Products to the economy, this is as a result of seventy-five percent ( 75\%) recorded in the overall calculation of scale value responded to by the participants unlike the group B which scored over all twenty-five percent (25\%).The implications are discussed among the followings; 1.Experiences on the Job: The culture of using modernized equipment has widen their mental horizons to designing and manufacturing related products unlike the self-employed who remain on the same spot. This is in support of Columbia Encyclopedia (2001).

2. Innovation and patronages: Because of the above, the firm creatively cultivated the planting of timber and tree planting to serve as their raw materials which consequently attracted government projects to the firm and produces furniture to hotels, governmental ministries within and outside its environs. This supported by Friedman (1982).

3. Values: The personal and corporate organizational values of the firm increased because the technical production of furniture created public images that attracted the former President of the Federal Republic of Nigeria, Retired General \& Chief Olusegun Aremu Obasanjo to the firm. This is in support of Van Ark (1992).

4.Personal development and career development: Apart from the entrance level of a basic skill the employees at the company group had initially, they had acquire several skills associated with the job and are also engaging in overtime duties, adjunct trainee in corporate and individual organizations. They not only created jobs but that technical skills they learnt created jobs for them even while their counterparts with university education are unemployed, they are the ones employing them as casuals and labourin their technical fields and firms as clerical and administrative personnel on meager incomes. What an irony which the writer used in theintroduction. Permit to report to my audience that the chief executive officer/managing director of the private company, Chief Bisi Rodipe was a product of Government Technical College, Ijebu Ode, Ogun State, Nigeria. This is in support of Domoniquinhos et al (2008).

5.Higher contribution to the economy: The furniture industry enjoyed public and private patronages attracted trainees from neighboring countries who after years of training are employed by the firm, some went back home to start theirs while the small village hosting the firm developed significantly. More importantly the firm now exports furniture materials to neighboring countries which add to the foreign exchange of Nigeria. The economic implication lies in the fact that if we have manyor more of these vocational industries, Nigeria's economy would have grown industrially as China and Japan currently enjoys now and would sustain them. Therefore, the Malaysia path to strong and world power in technology and industrial growth is a sound footing on the path of Globalisation which Nigeria and Africa must wake up from slumber and vocationalising and technicalising our primary and secondary schools. This is in support of UNESCO\&ASIA Collaboration on Regional Development Initiative.

\section{Identification Of Gaps/Challenges In Technical\&Vocational Education \\ 1. Nonrecognition of localcraftsmen. \\ 2. Inadequate funding. \\ 3. Lack of developmental blue-print.}


4. Lack of statistical data on craftsmen and society values.

5. Lack of co-operation between agencies and ministries related to revitalizing technical and vocational education.

6. Inadequate and sometimes a lack of support from the Government policy.

7. Non provision of infrastructural facilities to the local craftsmen and artisans.

8. Lack of progression of policy from the basics to the specifics.

9. The societal orientations and psychological belief in technical and vocational services.

10. Inadequateinternational support to Africa on effective transformation of our educational system because it requires huge human and material resources to actualize.

In view of the above, the following suggestions and recommendations are put forward for deliberations and applications to establish,develop,improve,concretise and sustain the degree of successes and weaknesses/challenges envisaged along the path of wealth creation, job production and values driven individual and society are as follows;

1. Entrenching/Incorporating pre vocational and technical subjects' skill in secondary schools.

2. Industrial reserved areas should be established and equipped with state of the art facilities by Government to boost the skills and experiences of local craftsmen for equalization with counterparts in company producing same services and products.

3. Courses at the technical colleges and colleges of technology should reflect the needs of the nation.

4. Industrial work experience scheme should be functional, for example the technology students should be made to have their industrial attachments in international industries in the country.

5.International companies and industries should train students in technological and vocational skill in their industries and also serve as adjunct instructor to technical colleges and vocational schools to integrate theory,experiences,practices which will generate and sustain interests of students at early stage of life to technical and vocational related skills.

6. The pedagogy of teaching technical and vocational subjects should be practically oriented and emphasized in order not to drive away those who are academically weak from it.

7. Provisionof instructional materials and instructors should be vigorously pursued by sending some to developed countries.

8. Secondaryvocational, technical and vocational education should be progressively related and developed to the tertiary institutions.

9. The large percentage of our country's budget should be earmarked to technical and vocational education instead of the old practice of devoting largest percentage to defence and politics. Thewriter of this paper postulate largest amount to implement this component of education will create individual with jobs who shuns violence, build entrepreneurship value on citizens who sees his call to service in politics as a clarion call to sustain the society industrially, technically and vocationally. We should learn from the establishment of vocational secondary from America, this is a good and cultural value politics Africa should emulate.

10.Establish enterprise culture through giving business loans to students and craftsmen who progressed in the technical and vocational fieds,give scholarships to instructors,students.concurrently,give accolades and inservice trainings, organize conferences and workshops to owners and operators of technical and vocational fields which will grow to National Passion to be producers, creators and innovators now and in the future.

\section{Conclusion}

Revolutionizing technical and vocational education is the best and sure path to scientific, educational, technological advancement of the next century of the era of Globalisation since no nation can rise above its level of education, theurgency, commitment and funding allocated to this component of education will point the direction of the world, each continent, country's attainment to sustainability in the era of Globalisation.

\section{References}

[1]. Columbia Encyclopedia, 6th ed.Columbia University Press 2001.

[2]. Domuguihos,P. Carvalho,L.et al(2009).Entrepreneurship, methodologies in Higher Education Economics and Management Department, BusinessSchool, Polytechnic Institute of Setubal.

[3]. Ekpenyong, L.E.(2010).Business Education and Entrepreneurship in Nigeria: The Missing Link. A lead paper presented at the Annual National Conference of Association of Business Educators of Nigeria at the Federal College of Education, Osiele, Abeokuta, in Ogun State, Nigeria.

[4]. Ekpenyong,L.E.(2007).Vocationalization of Education in Nigeria. A myth or reality

[5]. Fayolle, Allain (2009).Entrepreneurship education in Europe: Trends and Challenges.OECD Universities, Innovation and Entrepreneurship-Workshop Practice.

[6]. Federal Ministry of Education (2004).National Policy on Education, Lagos.

[7]. Friedman, Milton: Capitalism and Freedom. University of Chicago Press, 2nd edition 1982.

[8]. The Nigerian Vanguards Dec.2004 captioned "Neglect of technical and vocational education increases youth unemployment".

[9]. UNESCO\&ASIA (2013).Collaboration on Regional Development.

[10]. Van Ark\&Bart(1992).Vocational education and productivity in the Netherlands and Britain.

[11]. Victor,E.Dike (2009).Vocational education: Missing link in Nigeria's Development and policy.

[12]. Wikipedia definitions. 